\title{
PEMBUATAN ZONA EDUKASI UNTUK PENGEMBANGAN LINGKUNGAN EDUKATIF DI RW 08 KELURAHAN BALAS KLUMPRIK KECAMATAN WIYUNG KOTA SURABAYA
}

\author{
Deny Kuswahono \\ Universitas Wijaya Putra
}

denykuswahono@uwp.ac.id

\begin{abstract}
Abstrak
Kegiatan pembuatan zona edukasi yang dilaksanakan di RW 08 Kelurahan Balas Klumprik Kecamatan Wiyung Kota Surabaya ini bertujuan untuk mewujudkan lingkungan kampung yang lebih berorientasi pada ilmu pengetahuan dan budaya. Selain itu, kegiatan ini juga bertujuan untuk menjadikan kampung sebagai Pusat Kegiatan Belajar Masyarakat (PKBM) yang merupakan salah satu indikator dari salah satu aspek dalam program Kampung Pendidikan "Kampunge Arek Suroboyo" (KP-KAS), yaitu aspek Kampung Belajar. Zona edukasi ini terdiri dari zona permainan tradisional, zona seni, dan zona informasi yang dilengkapi dengan mini map atau roadmap atau peta mini untuk memetakan zona-zona edukasi tersebut. Penelitian ini menggunakan metode deskriptif dan pendekatan kualitatif dengan desain studi kasus. Teknik pengumpulan data dalam penelitian ini adalah observasi, dokumentasi, dan wawancara. Dengan adanya zona edukasi ini diharapkan nantinya dapat menjadikan RW 08 Kelurahan Balas Klumprik sebagai kawasan yang menggerakkan masyarakat dengan aktivitas-aktivitas positif dan kreatif. Pembelajaran bisa didapatkan melalui kegiatan berkesenian dan memainkan bermacam-macam permainan tradisional di zona seni dan zona permainan tradisional yang memperkenalkan budaya asli bangsa Indonesia kepada generasi muda untuk menetralisir derasnya pengaruh budaya asing. Selain itu, zona informasi diharapkan dapat menambah ilmu pengetahuan dan wawasan serta meningkatkan kreativitas warga.
\end{abstract}

Kata Kunci : budaya, ilmu pengetahuan, kreativitas, pendidikan, zona edukasi

\section{PENDAHULUAN}

Masyarakat yang hidup di era globalisasi dituntut untuk terus berkembang dan tidak ketinggalan informasi. Hal ini tentunya membutuhkan program-program yang mendukung jalannya pengembangan masyarakat baik berkembang dari segi pendidikan maupun dari segi sosial budaya. Program-program tersebut seyogyanya mengutamakan dan memanfaatkan sumber daya alam yang ada dan sumber daya manusia di sekitarnya. Sebagai proses perubahan yang terencana kearah kondisi yang lebih baik, pengembangan dapat diartikan sebagai proses perbaikan material maupun sosio-kultural dan usaha memajukan kehidupan spiritual suatu masyarakat. Upaya pengelolaan dari perspektif pendidikan non formal tentu akan lebih mengutamakan kebutuhan masyarakat itu sendiri dengan mengelola sumber daya yang ada, baik sumber daya alam dan juga sumber daya manusia. Melihat fenomena yang ada sekarang ini, banyak upaya pengembangan dan pengelolaan yang memanfaatkan sumber daya alam dan sumber daya manusia dengan menjadikan hal tersebut sebagai obyek lahan pemberdayaan masyarakat dengan mendapatkan banyak keuntungan untuk pemberdayaan itu sendiri.

$$
\text { Ekonomi, Sosial, dan Budaya }
$$


Pemberdayaan masyarakat dengan memanfaatkan sumber daya yang ada dapat dijadikan potensi untuk kepentingan masyarakat itu sendiri. Pemberdayaan tersebut adalah dengan cara memanfaatkan potensi dari masyarakat lokal dalam membentuk sebuah kampung yang memiliki kegiatan-kegiatan yang mengandung nilai-nilai edukasi yang bermanfaat bagi warga kampung itu sendiri. Pemberdayaan masyarakat menjadi salah satu pendekatan pembangunan yang dinilai dapat membuat masyarakat mandiri. Pendekatan pembangunan yang sifatnya top-down sudah mulai beralih pada pendekatan pembangunan yang sifatnya bottom-up. Pendekatan dimana masyarakat hanya tinggal melaksanakan program bergeser dimana masyarakat terlibat langsung baik dalam perencanaan, pelaksanaan, maupun dalam evaluasi. Hal ini dimaksudkan agar masyarakat mampu berinisiatif untuk kehidupannya dan menjadikannya berkembang secara mandiri baik personal maupun kelompok untuk memecahkan permasalahan kehidupan yang dialami.

Pemberdayaan masyarakat, menurut Soetomo (2011: 66-67), merupakan kritik terhadap pendekatan pembangunan masyarakat yang sebelumnya berbasis pertumbuhan. Pendekatan pertumbuhan tersebut berorientasi pada peningkatan produktivitas guna mengejar pertumbuhan ekonomi secara cepat serta sifatnya yang sentralisasi, keseragaman, dan top-down. Pemberdayaan masyarakat untuk menciptakan lingkungan kampung yang memiliki nilai-nilai edukasi tentunya membutuhkan kreativitas yang tidak bisa dilepaskan dari budaya masyarakat setempat yang menjadi basis pengembangannya. Dalam konteks kebudayaan lokal ada yang disebut dengan kearifan lokal yang menjadi nilai yang sangat bermakna apabila diterjemahkan ke dalam bentuk fisik berupa kegiatan kreatif daerah setempat.

Menurut Sulistyani (2014: 77), pemberdayaan berasal dari kata "daya" yang berarti kekuatan atau kemampuan. Berdasarkan pengertian tersebut maka pemberdayaan dapat dimaknai sebagai suatu proses menuju berdaya atau proses untuk memperoleh daya atau kekuatan atau kemampuan dari pihak yang memiliki daya kepada pihak yang kurang atau belum berdaya. Pemberdayaan masyarakat menjadi sebuah upaya dalam penyadaran dan pemberian kekuatan atau kemampuan yang sebelumnya tidak dimiliki oleh masyarakat. Pemberdayaan masyarakat mengandung dua arti, yang pertama adalah to give power or authority atau memberikan kekuasaan, mengalihkan kekuasaan atau mendelegasikan otoritas kepada pihak yang kurang berdaya, sedangkan yang kedua adalah to give ability to or enable atau memberikan kemampuan atau keberdayaan serta memberikan peluang kepada pihak lain untuk melakukan sesuatu.

Pemberdayaan dapat dikatakan berhasil apabila masyarakat tahu, mengerti, faham, termotivasi, berkesempatan, memanfaatkan peluang, berenergi, mampu bekerjasama, tahu berbagai alternatif, mampu mengambil keputusan, berani mengambil resiko, mampu mencari dan menangkap informasi dan mampu bertindak sesuai dengan situasi. Pemberdayaan ditujukan pada sebuah penciptaan suasana atau iklim yang memungkinkan potensi masyarakat berkembang. Manusia tidak ada yang tidak memiliki potensi, melainkan belum mengetahuinya secara eksplisit, sehingga tugas pemberdayaan adalah bagaimana membangun daya dengan cara mendorong, memotivasi, dan membangkitkan kesadaran potensi yang ada.

Tujuan yang ingin dicapai dari pemberdayaan adalah untuk membentuk individu dan masyarakat menjadi mandiri. Kemandirian tersebut meliputi kemandirian berpikir, bertindak, dan mengendalikan apa yang mereka lakukan tersebut. Lebih lanjut perlu ditelusuri apa yang sesungguhnya dimaknai sebagai suatu masyarakat yang mandiri. Kemandirian masyarakat adalah merupakan suatu kondisi yang dialami masyarakat yang ditandai oleh kemampuan untuk memikirkan, memutuskan, dan melakukan sesuatu yang dipandang tepat demi mencapai pemecahan masalah-masalah yang dihadapi dengan mempergunakan daya dan kemampuan yang terdiri atas kemampuan kognitif, konatif, psikomotorik, dan afektif dengan pengerahan sumber daya yang dimiliki oleh lingkungan internal masyarakat tersebut. Dengan demikian, untuk menuju kemandirian perlu dukungan kemampuan berupa sumber daya manusia yang utuh dengan kondisi kognitif, konatif, psikomotorik, dan afektif yang baik dan sumber daya lainnya yang bersifat fisik-material. Kondisi kognitif pada hakikatnya merupakan kemampuan

$$
\text { Ekonomi, Sosial, dan Budaya }
$$


berpikir yang dilandasi oleh pengetahuan dan wawasan seseorang atau masyarakat dalam rangka mencari solusi atas permasalahan yang dihadapi. Kondisi konatif merupakan suatu sikap perilaku masyarakat yang terbentuk yang diarahkan pada perilaku yang sensitif terhadap nilai-nilai pembangunan dan pemberdayaan. Kondisi afektif adalah sense yang dimiliki oleh masyarakat yang diharapkan dapat diintervensi untuk mencapai keberdayaan dalam sikap dan perilaku. Kemampuan psikomotorik merupakan kecakapan keterampilan yang dimiliki oleh masyarakat sebagai upaya pendukung bagi masyarakat dalam rangka melakukan aktivitas pembangunan.

Suparjan dan Suyatna (2013: 101) menyatakan bahwa pemberdayaan masyarakat menjadi suatu hal yang penting sebagai upaya peningkatan kondisi masyarakat yang awalnya tidak peduli menjadi peduli, yang tidak berdaya menjadi berdaya dan mendorong masyarakat mengubah relasi yang lebih kuat dalam menentukan masa depannya. Sifat pemberdayaan dimulai dari masyarakat itu sendiri untuk berubah menjadi individu yang mandiri sebagai tujuan dari pemberdayaan. Dalam memenuhi pemberdayaan tersebut, masyarakat dituntut untuk aktif dalam berpartisipasi dan membuka diri untuk menambah kapasitas mereka sebagai kekuatan untuk mencapai kekuasaan sehingga dapat dikatakan berdaya.

Wulan (2013: 81) mengutarakan bahwa konsep pemberdayaan merupakan proses untuk membuat masyarakat berdaya, dalam artian masyarakat memiliki kekuatan dalam mengelola potensi-potensi yang ada di sekitarnya, serta kemampuan dalam menciptakan kemandirian dalam diri mereka. Konsep pemberdayaan masyarakat ini tidak lain adalah usaha dalam meningkatkan kemampuan masyarakat dalam membawa dirinya ke arah yang lebih baik. Selain itu konsep pemberdayaan masyarakat ini juga berusaha untuk menciptakan kesadaran, pemahaman, pemanfaatan, dan pembiasaan agar tujuan dari sebuah program bisa tercapai dan keinginan dalam memberdayakan masyarakat bisa terwujud. Pada konsep pemberdayaan dijelaskan pula bahwa terdapat beberapa indikator tingkat keberhasilan suatu pemberdayaan, yaitu kemampuan masyarakat dalam mengelola potensi yang ada di sekitarnya menjadi meningkat, kesadaran masyarakat akan pentingnya suatu tujuan yang ingin mereka capai, dan pembiasaan diri dari masyarakat untuk berbuat sesuatu hal yang lebih baik dari sebelumnya. Beberapa indikator tersebut menjadi hal mendasar dari keberhasilan pemberdayaan yang dilakukan oleh seorang pelopor atau pemimpin dalam mencapai tujuan untuk menyelesaikan permasalahan terkait dengan ketidakberdayaan masyarakatnya.

Sumadyo (2009: 113) merumuskan tiga upaya pokok dalam setiap pemberdayaan masyarakat, yang disebutnya sebagai Tri Bina, yaitu Bina Manusia, Bina Usaha, dan Bina Lingkungan. Bina Manusia merupakan upaya yang pertama dan utama yang harus diperhatikan dalam setiap upaya pemberdayaan masyarakat yang dilandasi oleh pemahaman bahwa tujuan pembangunan adalah untuk perbaikan mutu hidup atau kesejahteraan manusia. Termasuk dalam upaya Bina Manusia, adalah semua kegiatan yang termasuk dalam upaya penguatan/pengembangan kapasitas. Bina Usaha adalah suatu upaya yang penting dalam pemberdayaan, sebab Bina Manusia yang tanpa memberikan dampak atau manfaat bagi perbaikan kesejahteraan tidak akan laku dan bahkan menambah kekecewaan. Sebaliknya, hanya Bina Manusia yang mampu (dalam waktu dekat/cepat) memberikan dampak atau manfaat bagi perbaikan kesejahteraan yang akan laku atau memperoleh dukungan dalam bentuk partisipasi masyarakat. Sedangkan Bina Lingkungan, sejak dikembangkannya mazhab pembangunan berkelanjutan (sustainable development), juga menjadi isu yang sangat penting. Hal ini terlihat pada kewajiban dilakukannya AMDAL (analisis manfaat dan dampak lingkungan) dalam setiap kegiatan investasi. Hal ini sangat penting, karena pelestarian lingkungan (fisik) akan sangat menentukan keberlanjutan kegiatan investasi maupun operasi (terutama yang terkait dengan ketersediaan bahan baku).

Kegiatan pembuatan zona edukasi yang dilaksanakan di RW 08 Kelurahan Balas Klumprik Kecamatan Wiyung Kota Surabaya yang merupakan obyek dalam studi ini bertujuan untuk mewujudkan lingkungan kampung yang lebih berorientasi pada pendidikan, ilmu pengetahuan,

$$
\text { Ekonomi, Sosial, dan Budaya }
$$


dan budaya. Kegiatan pembuatan zona edukasi tersebut juga bertujuan untuk menjadikan kampung sebagai Pusat Kegiatan Belajar Masyarakat (PKBM) yang merupakan salah satu indikator dari salah satu aspek dalam program Kampung Pendidikan "Kampunge Arek Suroboyo" (KPKAS), yaitu aspek Kampung Belajar. Zona edukasi ini terdiri dari zona permainan tradisional, zona seni, dan zona informasi yang dilengkapi dengan mini map atau roadmap atau peta mini untuk memetakan zona-zona edukasi tersebut.

\section{METODE}

Studi ini menggunakan metode deskriptif dan pendekatan kualitatif dengan desain studi kasus. Menurut Dornyei (2007: 23), penelitian kualitatif adalah interpretif, yang berarti bahwa hasil dan output dari penelitian tersebut adalah benar-benar produk interpretasi dari peneliti secara subyektif terhadap data yang diperoleh. Penelitian ini bertujuan untuk mendeskripsikan masalah, secara historis-sistematis, faktual, dan akurat, dengan menggunakan berbagai ilmu dan teori multidisiplin (Ratna, 2010: 112). Untuk menganalisa masalah budaya perlu melibatkan berbagai perspektif disiplin ilmu yang berlainan, seperti metode, teori dan ciri-ciri lain yang dapat digunakan untuk menganalisa fenomena budaya. Penelitian kualitatif tidak menekankan pada angka. Data yang terkumpul berupa kata-kata atau gambar.

Pendekatan penelitian kualitatif menurut Moleong (2015: 11) adalah penelitian yang menghasilkan data deskriptif berupa kata-kata tertulis atau lisan dari orang-orang dan perilaku yang dapat diamati. Penelitian kualitatif deskriptif merupakan salah satu metode penelitian kualitatif dimana data yang dikumpulkan berupa kata-kata untuk memberikan gambaran dari fenomena yang ada di lapangan. Metode penelitian kualitatif deskriptif dipilih untuk menemukan pemahaman tentang suatu fenomena tertentu.

Creswell (2010: 44) menyatakan bahwa penelitian kualitatif merupakan metode untuk mengeksplorasi dan memahami makna yang dianggap berasal dari masalah sosial atau kemanusiaan yang bersumber baik dari individu maupun sekelompok orang. Sehingga, dapat disimpulkan bahwa metode penelitian kualitatif adalah metode dalam mencari dan mengetahui apa yang terdapat dibalik fakta. Metode penelitian deskriptif kualitatif merupakan metode penelitian multi fokus, yang melibatkan penafsiran, pendekatan naturalistik dengan materi pelajaran yang ada. Metode penelitian kualitatif bertujuan untuk menggambarkan suatu fenomena tertentu, baik yang bersifat alamiah maupun rekayasa atau untuk menentukan ada atau tidaknya keterkaitan diantara suatu gejala dengan gejala lainnya yang relevan dengan penelitian.

Sedangkan studi kasus adalah suatu penelitian kualitatif yang berusaha menemukan makna, menyelidiki proses, dan memperoleh pengertian dan pemahaman yang mendalam dari individu, kelompok, atau situasi (Moleong, 2015: 134). Sudi kasus dapat digunakan dalam menjawab pertanyaan penelitian seperti bagaimana (how) dan mengapa (why). Penelitian yang menggunakan studi kasus biasanya karena adanya masalah atau hambatan, tetapi tidak menutup kemungkinan karena keberhasilan atau keunggulannya.

Sumber data dalam studi ini adalah zonazona edukasi yang terdiri dari zona permainan tradisional, zona seni, dan zona informasi di RW 08 Kelurahan Balas Klumprik Kecamatan Wiyung Kota Surabaya. Teknik pengumpulan data yang dilakukan dalam studi ini adalah observasi, dokumentasi, dan wawancara.

Observasi adalah teknik penelitian yang dilakukan dengan cara mengamati obyek kajian yang diteliti (Sugiyono, 2016: 314). Hal yang harus diamati adalah terkait dengan place (tempat/lokasi), actor (pelaku), dan activities (kegiatan). Teknik pengumpulan data melalui observasi adalah dengan mengoptimalkan kemampuan peneliti dari berbagai segi untuk menangkap sebuah fenomena yang bisa dijadikan sebagai data dan pengetahuan bagi penelitian yang dilakukan (Moleong, 2015: 174175). Observasi yang dilakukan dalam studi ini yaitu mengamati secara langsung proses kegiatankegiatan yang dilakukan di zona-zona edukasi di RW 08 Kelurahan Balas Klumprik Kecamatan Wiyung Kota Surabaya.

Sedangkan dokumentasi adalah teknik pengumpulan data yang dilakukan dengan cara menguraikan atau mempelajari data yang ada terlebih dahulu. Dokumentasi merupakan catatan peristiwa yang sudah berlalu, bisa berbentuk Ekonomi, Sosial, dan Budaya

1333 
tulisan, foto, gambar, atau karya-karya monumental dari seseorang. Teknik dokumentasi merupakan pelengkap dari penggunaan teknik observasi dan wawancara dalam penelitian kualitatif (Sugiyono, 2016: 329).

Teknik dokumentasi telah lama dipergunakan dalam penelitian sebagai sumber data karena dalam banyak hal dokumen sebagai sumber data dimanfaatkan untuk mengkaji, menafsirkan, bahkan untuk meramalkan. Teknik dokumentasi digunakan untuk memperoleh data berupa catatan tertulis, foto kegiatan, peristiwa maupun wujud karya kegiatan, dokumen pribadi, dan/atau dokumen resmi yang tersedia dari sumber informasi. Dalam studi ini, dokumentasi dilakukan dengan cara mempelajari dan mencatat aktivitas-aktivitas yang dilaksanakan oleh masyarakat setempat di zona-zona edukasi tersebut.

Wawancara adalah teknik pengumpulan data yang dilakukan melalui suatu percakapan yang dilakukan oleh dua belah pihak, yaitu pewawancara dan terwawancara dengan maksud tertentu (Stainback dalam Sugiyono, 2016: 318). Melalui wawancara, peneliti atau pewawancara bisa mendapatkan pemahaman yang lebih dalam tentang bagaimana terwawancara menginterpretasikan sebuah situasi atau fenomena tertentu. Dengan kata lain, peneliti bisa mendapatkan pemahaman yang mendalam dan informasi yang lebih jauh melalui wawancara, yang biasanya tidak bisa ditemukan dalam teknik observasi.

Dalam studi ini, wawancara dilakukan oleh peneliti terhadap bapak Ketua RW 08, bapak Ketua Karang Taruna, dan lima warga RW 08 yang rajin mengikuti kegiatan-kegiatan di zona-zona edukasi. Tujuan peneliti melakukan wawancara tersebut adalah untuk mempermudah saat menganalisis data. Wawancara dilakukan untuk mendapatkan informasi yang mungkin tidak peneliti dapatkan pada saat observasi.

Analisis data dalam penelitian kualitatif, menurut Bogdan (dalam Sugiyono, 2016: 334), adalah proses mencari dan menyusun secara sistematis data yang diperoleh dari hasil wawancara, catatan lapangan, dan bahan-bahan lain sehingga mudah dipahami dan temuannya dapat diinformasikan kepada orang lain. Analisis data dilakukan dengan mengorganisasikan data, menjabarkan ke dalam unit-unit, melakukan sintesa, menyusun ke dalam pola, memilih mana yang penting dan yang dipelajari, dan membuat kesimpulan yang dapat diceritakan kepada orang lain. Teknik analisis data dalam studi ini dilakukan pada saat pengumpulan data secara interaktif dan berlangsung secara terus menerus sampai tuntas. Teknik analisis data yang dilakukan adalah mendeskripsikan aktivitas-aktivitas yang dilaksanakan oleh masyarakat setempat di setiap zona edukasi.

\section{HASIL DAN PEMBAHASAN}

Dari data di lapangan didapatkan bahwa pengelolaan Kampung Edukasi RW 08 Kelurahan Balas Klumprik Kecamatan Wiyung Kota Surabaya adalah menciptakan kawasan yang berorientasi pada ilmu pengetahuan dan budaya dalam satu lingkup. Pembagian zona seni, zona permainan tradisional, dan zona informasi dapat dilihat pada mini map atau roadmap atau peta mini yang ada di kampung tersebut. Pemberdayaan masyarakat yang dilakukan di kawasan ini adalah melalui penyadaran warga dan pengelolaan potensi masing-masing individu.

Zona permainan tradisional adalah sebuah tanah lapang yang dulunya biasa digunakan oleh anak-anak warga kampung untuk bermain bola plastik dan bersenda gurau. Kadang-kadang digunakan pula oleh ibu-ibu untuk bercengkerama dan kadangkala digunakan oleh para remaja setempat untuk bermain bola voli ala kadarnya. Tanah lapang ini kemudian disulap sedemikian rupa oleh warga setempat atas kesadaran mereka sendiri menjadi zona dimana mereka, terutama anak-anak dan remaja, memainkan permainan-permainan tradisional khas tempo dulu yang sudah jarang dimainkan oleh anak-anak dan remaja Surabaya saat ini, seperti petak umpet, gobak sodor, lompat tali, bekel, dakon, patelele, dan gaple. Zona ini sengaja diciptakan untuk melestarikan permainanpermainan tradisional tersebut dan memperkenalkannya kembali kepada generasi muda yang lebih familiar dengan online game dan permainan-permainan yang ada di gadget, smart phone, komputer, dan sebagainya.

Zona seni sebenarnya adalah Balai RW 08 . Di dalamnya terdapat alat-alat musik seperti gitar

$$
\text { Ekonomi, Sosial, dan Budaya }
$$


klasik, ketipung, kendang, angklung, dan seperangkat gamelan. Selain sebagai tempat rapat RW, balai tersebut juga dijadikan sebagai area dimana masyarakat setempat memainkan atau mempelajari kesenian-kesenian khas rakyat Indonesia, seperti tari-tarian tradisional asli Indonesia, terutama Jawa, dan alat-alat musik dengan lantunan lagu-lagu khas Surabaya/Jawa dan Indonesia, seperti Rek Ayo Rek, Surabaya, KebyarKebyar, Gambang Suling, Rujak Uleg, Semanggi Suroboyo, Lir Ilir, Sewu Kutho, Lingsir Wengi, Yen Ing Tawang Ono Lintang, dan lain-lain. Warga setempat sudah bersepakat dan berkomitmen bahwa di dalam zona seni tidak boleh memainkan taritarian yang bukan asli Indonesia dan juga tidak boleh memainkan lagu-lagu asing.

Keberadaan zona seni memang dimaksudkan untuk menetralisir derasnya pengaruh budaya asing melalui lagu-lagu dan tari-tariannya, terutama budaya-budaya barat, India, dan Korea yang saat ini sedang menjadi trend di kalangan generasi muda. Dana pengadaan alat-alat musik seperti gitar klasik, ketipung, kendang, angklung, dan seperangkat gamelan bersumber dari swadaya masyarakat setempat. Hal ini dapat terwujud disebabkan oleh karena komitmen yang kuat dari para warga sendiri. Untuk mempelajari tari-tarian tradisional dan alatalat musik tersebut, warga sengaja mendatangkan guru tari dan guru musik dimana dana honorariumnya juga berasal dari swadaya warga.

Disamping itu, warga sudah merencanakan untuk membangun tempat khusus sebagai zona seni menggantikan Balai RW yang selama ini digunakan. Warga sedang berusaha mengumpulkan uang untuk mewujudkan hal tersebut karena biaya yang dibutuhkan tidak sedikit. Dibutuhkan ruangan indoor untuk zona seni untuk melindungi seperangkat alat-alat musik yang ada agar tidak rusak oleh panasnya sinar matahari dan air hujan. Tampaknya, keinginan dan cita-cita warga akan segera terwujud dalam jangka waktu yang tidak terlalu lama mengingat komitmen dari warga yang begitu kuat.

Zona informasi adalah zona yang diciptakan sebagai penyedia informasi bagi warga setempat. Zona ini merupakan sebuah taman dengan tanamantanaman asri yang terawat dan terdapat sebuah masjid yang tidak terlalu besar tempat warga melaksanakan sholat Jumat dan sebuah perpustakaan mini di dalamnya. Taman tersebut diberi nama Taman Baca dan dilengkapi dengan beberapa buah kursi panjang dan lampu-lampu penerangan yang dapat digunakan oleh warga untuk beristirahat dan bersantai sambil membaca bukubuku atau majalah dari perpustakaan mini. Taman Baca tersebut dilengkapi dengan peraturan "Dilarang Merokok" untuk melindungi kesehatan warga yang membaca atau bersantai di dalamnya.

Di dalam perpustakaan mini terdapat beberapa buah buku, koran terbaru, dan majalah terbaru yang bebas dibaca oleh warga baik di dalam perpustakaan maupun di area Taman Baca, dilengkapi dengan peraturan tertulis yang menyebutkan bahwa buku, koran, atau majalah yang sudah selesai dibaca harus dikembalikan ke perpustakaan. Dana pengadaan buku-buku, koran, dan majalah tersebut juga berasal dari swadaya warga setempat. Majalah-majalah yang ada selalu diperbarui setiap tahun sehingga warga tidak mengkonsumsi informasi yang sudah out of date. Zona ini dimaksudkan untuk memberikan informasi, wawasan, dan pengetahuan yang seluasluasnya bagi warga setempat.

Hasil penelitian menunjukkan bahwa partisipasi dari masyarakat dalam membangun zona-zona edukasi dan juga menyukseskan program Kampung Edukasi memang tidak dilakukan oleh seluruh warga, tetapi sebagian besar warga terlibat. Keberhasilan yang didapatkan saat ini tidak dipengaruhi oleh faktor gender, usia, tingkat pendidikan, dan latar belakang ekonomi dan sosial. Keterbukaan manajemen keuangan memiliki pengaruh yang kuat dalam membangun citra dan kepercayaan dari masyarakat. Keterbukaan akan membangun kepercayaan dan meminimalkan resistensi yang terbentuk di masyarakat. Selain itu, keterbukaan yang juga perlu diperkuat adalah peran dan keterlibatan. Semua warga RW perlu diberi kesempatan dan dorongan untuk terlibat dan berpartisipasi aktif dalam mengelola program Kampung Edukasi.

\section{KESIMPULAN}

Pemberdayaan merupakan konsep pembangunan yang memiliki banyak jalan yang bisa ditempuh. Salah satu jalan pemberdayaan yaitu melalui pemanfaatan potensi-potensi yang ada dan

Ekonomi, Sosial, dan Budaya

1335 
dikembangkan sehingga bermanfaat bagi masyarakat itu sendiri. Pemanfaatan ini dilakukan dengan mensinergikan antara potensi-potensi yang ada sehingga mampu membentuk sebuah strategi pemberdayaan yang berkelanjutan.

Kesadaran masyarakat dalam melihat peluang menjadi penentu dalam perkembangan masyarakat itu sendiri. Ketika sebuah masyarakat sudah diperlihatkan dengan sebuah aktivitas yang menguntungkan dan masyarakat mampu mengikuti kegiatan tersebut maka dapat dikatakan bahwa masyarakat telah sadar dan mau berkembang. Kampung Edukasi RW 08 Kelurahan Balas Klumprik Kecamatan Wiyung Kota Surabaya dengan zona-zona edukasinya merupakan salah satu kawasan yang dapat dijadikan contoh untuk menginisiasi masyarakat agar lebih peka untuk melestarikan budaya-budaya asli bangsa Indonesia dengan praktik-praktik kegiatan yang ada di dalamnya. Kampung ini juga dapat dijadikan contoh dimana masyarakatnya sudah menyadari akan pentingnya informasi dan pengetahuan dan pentingnya budaya membaca untuk menambah wawasan. Warga kampung tersebut sudah berkomitmen untuk memanfaatkan potensi-potensi yang ada terkait sumber daya manusia dan finansial sebagai upaya pemberdayaan masyarakat.

\section{REFERENSI}

Creswell, John W. (2010). Research Design: Pendekatan Kualitatif, Kuantitatif, dan Mixed. Diterjemahkan oleh Achmad Fawaid. Yogyakarta: Pustaka Pelajar.

Dornyei, Zoltan. (2007). Research Methods in Applied Linguistics. Oxford: Oxford University Press.

Moleong, Lexy J. (2015). Metodologi Penelitian Kualitatif. Bandung: PT Remaja Rosdakarya.

Ratna, Nyoman K. (2010). Metodologi Penelitian; Kajian Budaya dan Ilmu Sosial Humaniora pada Umumnya. Yogyakarta: Pustaka Pelajar.
Soetomo. (2011). Pemberdayaan Masyarakat: Mungkinkah Muncul Antitesisnya. Yogyakarta: Pustaka Pelajar.

Sugiyono. (2016). Metode Penelitian Pendidikan Pendekatan Kuantatif, Kualitatif, dan R\&D. Bandung: Alfabeta.

Sulistyani, Ambar Teguh. (2014). Kemitraan dan Model-Model Pemberdayaan. Yogyakarta: Graha Ilmu.

Sumadyo. (2009). Pemberdayaan Masyarakat. Referensi Pemberdayaan Masyarakat. edisi revisi.

Suparjan dan Suyatna, Hempri. (2013). Pengembangan Masyarakat, dari Pembangunan sampai Pemberdayaan. Yogyakarta: Aditya Media.

Wulan, S. (2013). Jurnal Manajemen dan Bisnis Fakultas Ekonomi Program Studi Manajemen. Universitas Bandar Lampung Vol. 3 No. 2. 